\title{
COMPARING JOURNALISM CULTURES IN BRITAIN AND GERMANY:
}

\section{Confrontation, Contextualization, Conformity}

\author{
Imke Henkel, Neil Thurman, and Veronika Deffner
}

Many British newspapers proclaim strongly partisan political and moral positions, with headlines such as "Get Britain out of the EU." In contrast, German newspapers, during national events such as the refugee crisis, often take on the role of reflective observers. Previous comparative research has shown a link between journalists' output and professional attitudes. Using data from the Worlds of Journalism Study, this article analyses the professional attitudes of British and German journalists $(\mathrm{N}=1475)$ across three constituents of journalism culture: societal, epistemological, and ethical. Our analysis shows significant differences in all three constituents. We conclude that British journalists conceive of their professional role as more confrontational to those in power than their German colleagues. We also find some evidence that German journalists believe it more important to provide context and analysis - aiming to assist audiences in their civic roles - and that they are more likely to conform to professional codes, although only in general terms. Our findings contradict some earlier comparative studies that claimed a more passive role for British journalists. Our findings may also hold interest for others engaged in international comparative research, showing how the two-country comparison can identify, and account for, what is hidden in multi-country research designs.

KEYWORDS British and German; comparative; journalism's role in society; journalists; professional attitudes; role conception; Worlds of Journalism Study

\section{Introduction}

When we compare contemporary British and German news media, differences are instantly apparent. Among the most striking contrasts is the political positioning of newspapers in Britain and Germany: British front pages, especially of the tabloid press, can loudly advocate political or moral views, while German papers are often more reticent. During election campaigns, British papers frequently declare their support for one party. "Don't chuck Britain in the Cor-Bin" (The Sun, 8 June 2017) advised The Sun on the day of the 2017 general election, adding a photomontage of the Labour leader, Jeremy Corbyn, in a rubbish bin for clarity. On the same day, the Daily Mirror exclaimed "Lies, damned lies and Theresa May", 
and called on its readers not to "condemn Britain to five more years of Tory broken promises" (Daily Mirror, 8 June 2017).

German newspapers refrain from campaigning, and instead (at most) offer help and advice to allow their readers to decide for themselves. Ahead of the German elections in September 2017, Der Spiegel ran with the cover story "Klüger wählen. Eine Gebrauchsanweisung" or "How to vote smarter: A manual" (Der Spiegel, 16 September 2017). Even the tabloid Bild, which among German newspapers comes closest to campaigning (Tschermak 2017), merely suggested to its readers, ahead of the elections, "Was sich endlich ändern muss" or "What has to change" (Bild, 17 July 2017), presenting a manifesto of its own, rather than falling behind one of the political parties.

In Britain, newspapers and their editors can be seen as players in the power game of politics. When, in June 2018, Paul Dacre, editor of the Daily Mail, announced his departure, commentators pointed out that "the Mail under Dacre has been an extraordinary force in politics and the country" (Chorley 2018), and that "[a]ny change to the Daily Mail's editorial line on Brexit could have substantial implications for the government" (Waterson 2018). German editors instead launch projects to enable citizens to participate in political debate, such as Zeit Online's \#D17/\#D18 project (Bangel et al. 2018) or Süddeutsche Zeitung's Democracy Lab (Lindner et al. 2017).

In this article, we investigate whether these apparent differences between British and German media are rooted in two different journalism cultures. We approach this question through a survey of professional attitudes among British and German journalists. As Albæk et al. point out, "the rationale for studying role conceptions is based on the assumption that they influence journalists' work" $(2014,73)$. Put another way, what journalists hold to be the principles of their profession may have an impact on what they produce.

However, the scholarly literature is divided on the question of how closely journalistic performance can be linked to journalistic role conceptions. According to Donsbach, differences in both media systems and journalists' role perceptions are "consequential for journalists' performance" $(2015,317)$. Albæk et al. list a number of studies that establish a link between professional attitudes and journalistic outputs $(2014,74-75)$ and conclude that "we can expect to find a relationship between role conceptions and news content both at the level of individual journalists (micro) and when comparing across different journalistic cultures" (75). In a meta-study of communication research on the relation between attitudes and behaviour, Kim and Hunter (1993) found "uniformly positive correlations between 
attitude and behavior with a very high correlation if the attitude was highly relevant to the behavior" (128). Although this meta-study did not look at journalism research, journalistic role conceptions "define the professional identity of journalists" (Albæk et al. 2014, 74) and therefore, as Albæk et al. (2014) argue, can be conceived of as highly relevant to journalistic behaviour.

Other scholars, though, have questioned the extent to which journalistic outputs are a reflection of journalists' professional attitudes (Hellmueller and Mellado 2015). Some empirical studies show a gap between journalistic role conceptions and performance. Mellado and van Dalen (2014) compared the attitudes of Chilean journalists $(N=75)$ with news stories they produced $(N=628)$ and tested for six different professional roles. They found that "all roles are overall performed less than journalists would like", with the gap particularly wide for the watchdog and the civic-oriented role (868). Similarly, Tandoc, Hellmueller, and Vos (2013) investigated US and foreign correspondents in Washington $(N=56)$ and their news coverage, and found that routine influences (such as news deadlines or supervisors or colleagues in the organization) and the location of the news organization (in the US or abroad) were stronger predictors for the enactment of specific roles than role conceptions were.

However, these results do not render survey-based research of journalists' role conceptions meaningless. Although they warn us against assuming journalistic outputs will automatically conform to journalists' attitudes, they do not establish a complete disconnect between role conceptions and performance. On the contrary, where journalists are prevented from realizing their professional ideals, their organizational commitment suffers (PihlThingvad 2015). As Mellado and van Dalen $(2014,873)$ concede, survey studies of role conceptions still "offer valuable insight into the journalistic profession, for example in the particularity of journalistic cultures, both nationally and internationally”. Equally, Van Dalen, de Vreese, and Albæk $(2012,917)$ contend that they remain an important tool for explaining differences between journalism cultures.

\section{Journalism Cultures}

The concept of journalism culture has become an increasingly popular one in media research over the last two decades (Deuze 2002; Zelizer 2005; Hanitzsch 2007; Hanitzsch et al. 2011). 
Hanitzsch defines journalism culture "as a particular set of ideas and practices by which journalists, consciously and unconsciously, legitimate their role in society and render their work meaningful to themselves and others" $(2007,369)$. To make this concept operational for comparative research, Hanitzsch deconstructs the general notion of journalism culture into component parts. He makes a distinction between three "constituents" of journalism culture: institutional roles, epistemologies, and ethical ideologies. He further divides these three constituents into seven "dimensions", which can be operationalized along a scale of professional role conceptions. The institutional role dimension is composed of journalists' attitudes towards interventionism, power distance, and market orientation. The epistemologies comprise attitudes towards objectivism and empiricism. The ethical ideologies consist of relativism and idealism $(2007,371)$.

We will use this deconstruction of journalism cultures as a starting point to examine the specific British and German journalism cultures through an analysis of journalists' professional attitudes. In an analogue of Hanitzsch's subdivision, we will investigate three constituents of journalism culture: the societal (which roughly correlates with Hanitzsch's "institutional roles"), the epistemological, and the ethical. The societal constituent looks at journalists' relationships with those in power and with their audiences. The epistemological constituent concerns attitudes to factual reporting of the world. The ethical constituent investigates ethical ideology as well as attitudes towards questionable professional practices.

Comparative research on different journalism cultures became popular in the 1980s and 1990s as an instrument to better understand specific national characteristics, such as professional attitudes, by contrasting them with equivalent characteristics within the journalism culture of one or several other countries (Esser 1999, 294; Deuze 2002, 134-135; Donsbach and Patterson 2004, 251). In recent years, not least because of the Worlds of Journalism Study, ${ }^{1}$ comparative journalism research has increasingly moved into multicountry comparisons (Hanitzsch 2011; Hanitzsch et al. 2011; van Dalen, de Vreese, and Albæk 2012; Plaisance, Skewes, and Hanitzsch 2012; Albæk et al. 2014; Hanitzsch, Hanusch, and Lauerer 2016; Godler and Reich 2013). ${ }^{2}$ These comprehensive studies focus on mapping out journalistic cultures to explore their common characteristics far beyond the national level.

Our study builds on the concepts that have evolved in these studies but goes back to the beginnings of comparative research to examine two specific national journalism cultures by comparing the professional role conceptions held by German and British journalists. We 
revisit earlier comparisons of British and German journalism cultures in the light of newer conceptual research and with the focus on journalists' role in democratic societies. We attempt to determine whether the apparent differences in the positioning of some British and German newspapers are reflected in differences in the societal, epistemological, and ethical role conceptions of British and German journalists.

\section{Literature review}

A lot has been written about the biased British media, ${ }^{3}$ and scholars often comment on the partisan nature of the British press (e.g. Semetko et al. 1991; Curran, Gaber, and Petley 2005; Sanders and Hanna 2012; Gaber 2014; Umbricht and Esser 2014; Cammaerts et al. 2017). Hallin and Mancini (2004) observe that the British media system is an exception within the Liberal Media Model as it demonstrates much stronger "political parallelism" - "the extent to which media reflects political divisions" (Hardy 2008, 18) - than either the American or the Irish press, with the competitive British media market and the British political system providing possible explanations (Hallin and Mancini 2004, 213-216).

German newspapers, while not as aggressively biased in their behaviour as British newspapers, have still been found to pursue a political agenda, for example through the selection of sources. ${ }^{4}$ Hallin and Mancini point out the highly partisan history of the German press (2004, 155-156; see also Donsbach and Patterson 2004, 261), and a number of comparative studies have identified an advocative role conception among German journalists (Köcher 1986; Donsbach 1995; Donsbach and Klett 1993).

The comparative research investigating British and German journalists has consistently concluded that the groups differ from each other in their conceptions of their societal role and their ethical ideologies. The difference has been conceptualized in various ways over the last 40 years.

Two studies from the 1980s, based on surveys of journalists' views of how they should report reality, claimed that German journalists see themselves in a more politically active role, while British journalists stress the neutral information function of journalism.

Using data from a comparative survey undertaken by the Institut für Demoskopie Allensbach (for Germany) and the Centre for Mass Communication Research at the University of Leicester (for Britain), Donsbach (1983) found that "German journalists tend to perceive themselves as an active and political element within a democracy, whereas British 
[...] define the information function as their primary professional task" (34-35). Köcher (1986) based her study on face-to-face interviews with German $(N=450)$ and British journalists $(N=405)$ working for print (daily and weekly papers as well as news magazines) and broadcasting media (contributing editors in the fields of politics, business, local news, culture, and sports), with roughly two thirds of the interviewed journalists working for print. Higher ranking journalists (editors-in-chief, senior editors, directors, and head of departments) were deliberately over-represented (44). The survey combined questions about what attracts journalists to their profession with questions about abstract role conceptions, strategic preferences, and preferred decisions in a hypothetical situation (51-60). Köcher concluded that British journalists see their role as neutral reporters of an objective reality with a strong interest in uncovering the truth ("bloodhounds"), whereas German journalists perceive themselves as advocates ("missionaries"). ${ }^{5}$

In their comparative study of journalists' professional attitudes in the US $(N=278)$, Britain $(N=216)$, Germany $(N=338)$, and Italy $(N=292)$, Donsbach and Klett (1993) investigated different understandings of "objectivity" as "one of the core professional values of journalism" (53). They based their study on a mail survey targeting journalists who "participated in daily news decisions about politics and public affairs" (60). Newspaper and broadcast journalists were included in equal proportion. Half came from national media and half from local media (61). The questionnaire asked about institutional structures, journalists' social, economic, and educational backgrounds, and journalists' professional attitudes, as well as including several questions about their understanding of the term "objectivity" (5960). Like Köcher before them, Donsbach and Klett (1993) found a passive, "more restrained notion" among British journalists, whereas German journalists displayed a "more active and investigative" notion of objectivity (78). This finding was echoed ten years later in Donsbach and Patterson's (2004) similarly designed comparative study of German ( $N=303)$, Italian $(N=292)$, Swedish $(N=272)$, British (216), and US $(N=278)$ journalists, conducted between 1991 and 1993. They located British journalists on the side of neutral and passive journalists: "neutral reporter, mirror, common carrier, disseminator, broker messenger". Whereas the German journalists were on the advocate and active side: "ideologue, missionary, interpreter" (266).

Esser (1998a, 1998b, 1999, 2008; Esser, Reinemann, and Fan 2000) investigated the specific differences between British and German journalism cultures across a number of different criteria. Comparing Tony Blair's and Gerhard Schröder's election campaigns, Esser, 
Reinemann, and Fan (2000) used comparative content analysis of the press coverage of the British and German general elections in 1997 and 1998 to assert that spin doctoring was significantly more aggressive in Britain and also more extensively and critically reported by British journalists than in Germany. Their findings appear to be at odds with some of the other research we have mentioned that found British journalists on the neutral/passive side in regard to their professional role conceptions.

These differences, we believe, justify revisiting the question of how British and German journalists differ in their perception of their professional roles within the democratic societies of both countries. Our own anecdotal observations seem to suggest, in line with Esser's findings, that British journalists tend to see themselves as confrontational actors in society - what Hanitzsch calls "adversarial" - whereas German journalists are more likely to believe they have a role enabling citizens to participate in society. If our observations are reflected in journalists' role conceptions, we would, in contrast to some earlier research, expect British journalists to be more interventionist and adversarial than their German colleagues. If our assumption is true that German journalists, more than their British colleagues, tend towards a role as enablers for civic society, we would also expect journalists in Germany to be more inclined to perceive their audience as citizens than would journalists in the UK. If, in addition, British journalists are, indeed, more likely to see themselves as confrontational actors in the power game, they may tend towards reporting of "objective" facts, disseminating the "truth". Claiming "objectivity" is one way in which journalists can assert their professional power, making opposition to their version of reality a dispute with the "true" facts (see, e.g., Schudson and Anderson 2008). If, on the other hand, German journalists are, indeed, enablers of civic society, we might expect them to tend towards providing context and analysis to help citizens understand the world, implying that they are offering but one version of the truth among others, rather than reporting the "objective" facts. Finally, we would expect that journalists who perceive their role as confrontational actors within society would be more likely to adhere to an ethical ideology that relies on their own judgement rather than conforming to strict, given rules. Köcher contends that British journalists, because their "highest goal is satisfying the public's need for information", are prepared to justify "the use of dishonest research methods" $(1986,62)$. Our assumption that British journalists tend to see themselves as confrontational actors can lead us to expect that they are indeed more ready than their German counterparts to find justification for 
questionable ethical practices in fulfilling their professional role. As a result, we propose the following hypotheses:

H1: British journalists tend towards a more active or interventionist role conception than German journalists.

$\mathrm{H} 2$ : British journalists tend more towards a role conception as confrontational actors than German journalists.

H3: German journalists tend more towards seeing their audience as citizens than British journalists do.

H4: British journalists tend more towards a role conception that believes in factual reporting, whereas German journalists tend more towards an analytical role conception.

H5a: British journalists tend more than German journalists towards an ethical ideology that places importance in their own judgement rather than in fixed rules.

$\mathrm{H} 5 \mathrm{~b}$ : British journalists are more prepared than their German colleagues to find justification for questionable ethical practices.

\section{Methodology}

This study uses data from the Worlds of Journalism Study, which brings together researchers from 67 countries, including the UK and Germany. Between 2012 and 2016 over 27,500 journalists were interviewed across the world, using a common methodological framework (WJS 2012a). The British and German surveys both conformed to this framework, for example only sampling journalists from media organizations that had their own news programme or news section, so radio stations that only broadcast music programmes, for instance, were excluded. Only professional journalists who earned at least 50 per cent of their income from journalism and were involved in producing and editing journalistic content or in editorial supervision and coordination were included. This latter criterion meant, for example, that photojournalists were included but not camera operators unless they made editorial decisions independently (WJS 2012a, 1). Journalists who worked in purely administrative, organizational, or technical roles were excluded. Also not considered were journalists working for promotional media (such as publications produced by "contract" publishers for corporate clients), for websites whose primary purpose was to sell something, or for magazines published by companies owning retail premises. The British and German surveys 
also excluded amateur journalists and those working in a voluntary capacity. Both surveys included journalists from all media types: newspapers, magazines, television stations, radio stations, and online media, as well as news agencies.

The UK data were gathered - by one of this article's authors - in December 2015 from journalists listed in the Gorkana Media Database, the largest available database of UK journalists' contact details. From a total of 35,010 contact details, 5684 duplicate entries were removed. From the remaining database of 29,326 journalists, 30 per cent were selected at random and were invited, by email, to take part in an online survey. A total of 1292 surveys were started, and 715 fully completed. All the fully completed surveys were examined and journalists who were not considered to be professional journalists were excluded, leaving a UK sample of 700, which is equivalent to a response rate of 8 per cent. Comparisons with other surveys of journalists show that the UK sample appears to be representative of the larger population of journalists in the UK (Thurman 2016a, 57-58).

The German data were collected between November 2014 and August 2015 using a mixture of telephone and online surveys. In the German survey, newsrooms were identified by stratified random sampling taking into account media type, reach, and ownership. In a second step, particular journalists were randomly sampled within each newsroom. For the purposes of sampling, German newsrooms were classified as either small or large, with a maximum of five journalists interviewed in each large newsroom and a maximum of three in small newsrooms (Steindl, Lauerer, and Hanitzsch 2017, 412). Because the sampling strategy for the British survey did not use this size classification, our analyses keep the results for small and large German newsrooms separate.

The total population of professional journalists in Germany was estimated at 41,250. The final German sample was 775, the result of a response rate of 34.9 per cent. Of the German journalists surveyed, 69.2 per cent opted for a telephone interview and 30.8 per cent completed an online questionnaire (Steindl, Lauerer, and Hanitzsch 2017, 407-412).

In the question batteries of the Worlds of Journalism Study questionnaire (WJS 2012b) that ask about role conceptions, 5-point Likert items are used, with the response levels ranging from 1 for "unimportant" to 5 for "extremely important". The questions about questionable journalistic practices use Likert-type items with the following response levels: 1 for "always justified", 2 for "justified on occasion", and 3 for "not approve under any circumstances". 
Single items which measure role conceptions were combined into six scores, which mostly reflect Hanitzsch's constituents of journalism culture $(2007,371)$. We decided to measure the three dimensions of the societal (or "institutional", in Hanitzsch's terminology) constituent, "interventionism", “distance to power", and "market orientation", separately, because significant differences would have been hidden had we subsumed the three societal dimensions under one single score. On the other hand, we combined Hanitzsch's dimensions of "objectivism" and "empiricism" into a single score to measure "epistemological role conceptions". For the ethical constituent, we built one score to measure "ethical ideology", and a second score for "ethical practices".

Our model, therefore, builds separate scores for the three dimensions of the first (societal) constituent of journalism culture. It provides a single score for the epistemological constituent, and two scores for two separate aspects - the ideological and the practical - of the ethical constituent.

The association between country and journalists' attitudes was modelled using a multiple linear regression model with a random intercept. As found in other studies (e.g. Hovden 2014), journalistic role conception is, beyond the country affiliation, associated with several other factors, such as gender and education. Therefore, the model accounted for a number of covariates, including journalists' beat, education, rank, years worked in the industry, and age, as well as type, reach, and ownership of medium.

\begin{tabular}{|c|c|c|c|c|}
\hline & All & $\begin{array}{l}\text { Small } \\
\text { German } \\
\text { newsrooms }\end{array}$ & $\begin{array}{l}\text { Large } \\
\text { German } \\
\text { newsrooms }\end{array}$ & UK \\
\hline Interventionism & $2.809(0.875)$ & $2.882(0.787)$ & $2.825(0.857)$ & $2.758(0.928)$ \\
\hline Power distance & $3.531(0.672)$ & $3.509(0.714)$ & 3.429 (0.709) & 3.599 (0.618) \\
\hline Market orientation & $3.334(0.851)$ & $3.175(0.871)$ & $3.361(0.9)$ & $3.411(0.8)$ \\
\hline Epistemological role conceptions & $3.576(0.492)$ & $3.55(0.47)$ & $3.484(0.486)$ & $3.64(0.498)$ \\
\hline Ethical ideology & $3.946(0.675)$ & $4.098(0.581)$ & $4.092(0.607)$ & $3.781(0.721)$ \\
\hline Ethical practices & $2.511(0.277)$ & $2.509(0.265)$ & $2.516(0.28)$ & $2.51(0.282)$ \\
\hline
\end{tabular}

Table 1: Means (standard deviations) of scores measuring journalists' attitudes in the UK and in small and large German newsrooms. 5-point Likert items were used, with response levels ranging from 1 for "unimportant" to 5 for "extremely important". For "ethical practices' 3-point Likert-type items were used with the following response levels: 1 for "always justified", 2 for "justified on occasion", and 3 for "not approve under any circumstances". 


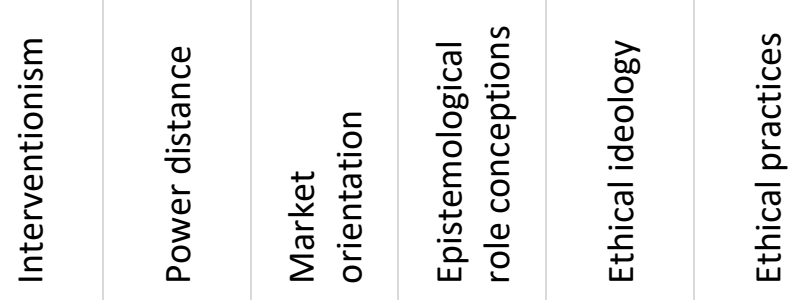

Beat (reference: generalist)

News/current affairs

$-0.319$

Political/economic beat

$0.32-0.368$

Non-political beat

$-0.136$

$-0.364 \quad 0.493$

Other beat

$-0.238$

Degree and specialization (reference: degree and no specialization)

No degree

Degree and specialized

$0.111-0.111$

Gender (reference: female)

Male

$-0.189$

$0.151 \quad-0.149$

$-0.13$

$-0.12$

Level of authority (reference: middle-level authority)

Most authority

Limited authority

$-0.123-0.056$

Type of medium (reference: not this type)

Daily newspaper

0.376

$0.334-0.313$

Weekly newspaper

$-0.118$

Magazine

Television

Radio

News agency

$0.235 \quad-0.331$

0.214

Online outlet (stand-alone)

Online outlet (of offline outlet)

$-0.073$

Reach of medium (reference: national)

$\begin{array}{lllll}\text { Local } & 0.199 & -0.24 & 0.124 & 0.078 \\ \text { Regional } & 0.167 & & 0.091 & 0.064\end{array}$

Transnational

0.18

Ownership of medium (reference: publicly owned)

\begin{tabular}{|c|c|c|c|c|}
\hline Not publicly owned & -0.207 & -0.28 & 0.41 & \\
\hline Working years & & 0.007 & & -0.005 \\
\hline Age (10 years) & & & 0.077 & 0.075 \\
\hline
\end{tabular}

Table 2: Estimated regression coefficients of the confounding variables. Only estimates which differ significantly from zero are shown (significance level: 0.05 ). 
The Version of Record of this manuscript has been published and is available in Journalism Studies (2018) http://www.tandfonline.com/10.1080/1461670X.2018.1551067

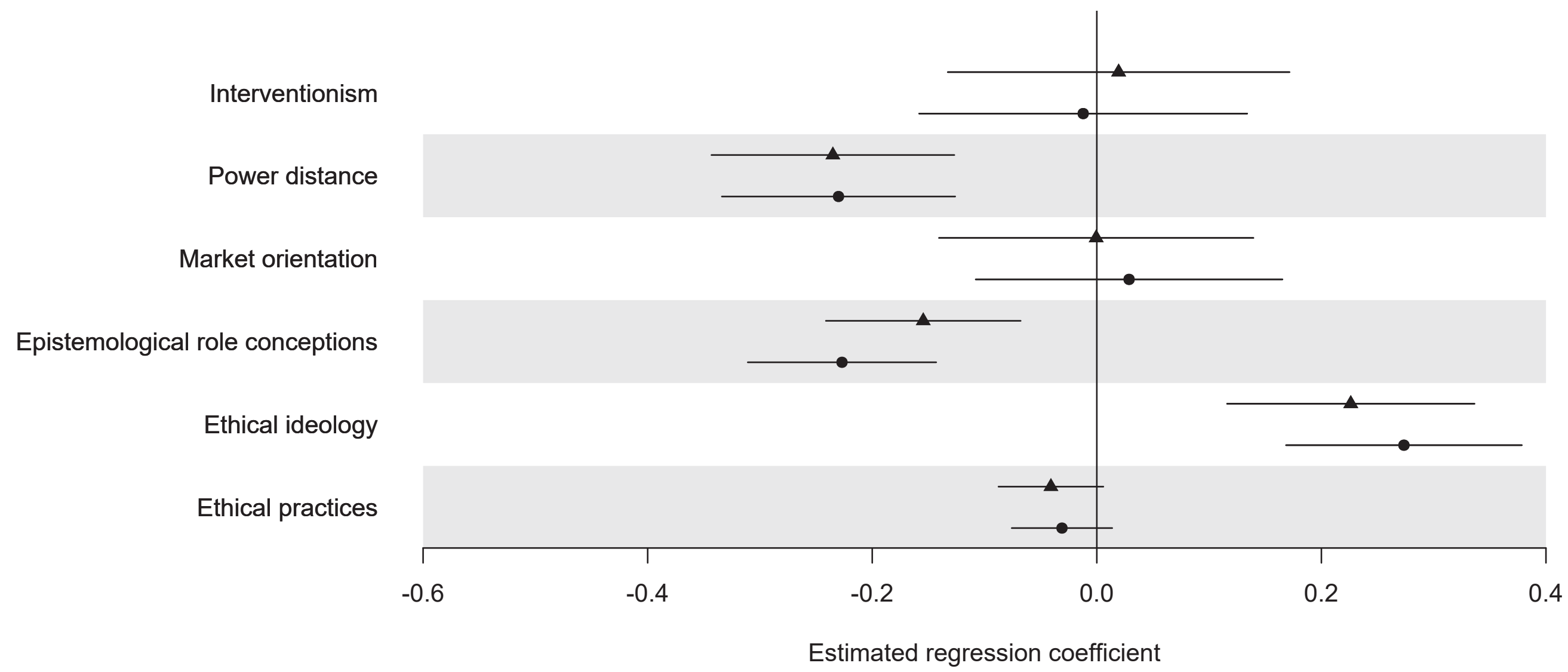

Figure 1: Estimated mean deviations (adjusted for confounding variables) between journalists' attitudes in small (triangles) and large (bullets) German newsrooms compared with British journalists (reference category). The lines mark the corresponding 95\% confidence intervals. 


\section{Results}

\section{Journalists' Conception of their Societal Role}

Based on Hanitzsch's (2007) classification of journalists' institutional roles, our analysis investigated how British and German journalists conceive their societal role through their attitudes towards interventionism and those in power, and the importance they ascribe to market considerations.

Interventionism. Following Hanitzsch (2007), this dimension "reflects the extent to which journalists pursue a particular mission and promote certain values" (372). Regarding attitudes towards interventionism, we looked at how British and German journalists position themselves in terms of setting the political agenda, influencing public opinion, advocating for social change, and promoting tolerance and cultural diversity. We combined these four roles into one score ranging from being passive and unlikely to intervene at one end to having a high degree of interventionism at the other. Both German and British journalists were very slightly more inclined towards the interventionist end of this scale, being "socially committed, and motivated" (ibid.) (see Table 1), but there were no significant differences at the country level (see Figure 1).

Our first hypothesis is, therefore, rejected. British journalists do not tend towards a more interventionist role conception than German journalists.

Our regression analysis shows that interventionism is influenced by gender, beat, and institutional factors: the type of medium for which journalists work, its reach, and whether it is privately or publicly owned (see Table 2). Male journalists conceive of their professional role as less interventionist than female journalists do, and journalists working on a nonpolitical beat conceive of their role as less interventionist than generalist journalists do. ${ }^{6}$ Journalists working for newsrooms in private ownership are significantly less interventionist in their beliefs than journalists working for media outlets in public ownership. In contrast, journalists working for media with local or regional reach are significantly more interventionist in their beliefs than journalists working for media with national reach. Also more interventionist are journalists working for daily newspapers. 
Power Distance. Our power distance score consists of five role conceptions: monitoring and scrutinizing political leaders, monitoring and scrutinizing business, being an adversary of government, and considering it unimportant to support government policy or to convey a positive image of political leadership. On the power distance score, British and German journalists differ significantly (see Figure 1). Whereas both groups, as the mean values suggest, are clearly closer to the "adversary" end of the power distance scale (see Table 1) and thus tend towards "a kind of journalism that openly challenges the powers that be" (Hanitzsch 2007, 373), this is less the case for German journalists.

This confirms our second hypothesis: British journalists do indeed tend more towards a role conception as confrontational actors than their German colleagues.

The regression analysis shows that journalists with a degree in journalism or another communication field lean, on average, more towards the adversary end of the power distance scale than journalists with a degree in another subject. The same is true for journalists working for news agencies or for a daily newspaper. A tendency towards the adversary end of the power distance scale is also found among male journalists, among journalists (male or female) working on a political/economic beat, and as the number of years journalists have worked in the industry increases. On the other hand, journalists working for magazines (compared with those that do not) as well as those working for privately owned outlets tend more towards the non-adversarial end of the power distance scale (see Table 2).

Market Orientation. The market orientation score combines beliefs about the importance of "providing entertainment and relaxation" and "the kind of news that attracts the largest audience". It also includes attitudes towards "providing information people need to make political decisions" and towards "motivating people to participate in political activity". This score measures whether journalists address their audience "as citizens or consumers" (Hanitzsch 2007, 374). It stretches between the two poles of providing entertainment and relaxation and the kind of news that attracts the largest audience (addressing the audience as consumers) at one end, and providing information people need to make political decisions and motivating people to participate in political activity (addressing the audience as citizens) at the other. We found no significant differences in market orientation at the country level (see Figure 1).

Therefore, our third hypothesis is rejected: German journalists do not tend more towards seeing their audience as citizens than British journalists do. 
The regression analysis shows that male journalists, on average, tend significantly more towards addressing their audience as citizens. We found the same to be true for journalists who cover a news/current affairs or a political/economic beat (when compared with generalists), for journalists with a degree in journalism or another communication field (compared to those without such a degree), for journalists working for news agencies and/or daily newspapers (compared with those that do not), and for journalists working for a newsroom with local reach (compared with journalists working for an outlet with national reach). Journalists not working for publicly owned media like the BBC, and those working on a non-political beat are more inclined to address their audience as consumers (see Table 2).

\section{Journalists' Conception of Epistemology}

The epistemological dimension is concerned with the perception of truth and how truth is obtained. Hanitzsch (2007) divides the dimension into objectivism and empiricism, where objectivism describes "the correspondence between mental impression and the true shape of the existent actual" (376), as opposed to the subjectivist view which holds that reality is always constructed through an individual perspective. Objectivist journalists assume "that reality, in principle, can be perceived and described 'as it is"” (ibid.).

Empiricist journalism emphasizes facts that can be verified through "observation, measurement, evidence, and experience" (Hanitzsch 2007, 377). On the other end of the empiricist spectrum sits the claim that truth can be verified through analysis (ibid.).

We investigated journalists' epistemological role conceptions, asking about the importance of three specific roles: "being a detached observer", "reporting things as they are", and "providing analysis of current affairs". The first corresponds to the empiricist role conception ("In its most radical form, this pole of the empiricism dimension leads journalists to merely record events and let 'the facts speak for themselves"' [Hanitzsch 2007, 377]), the second to the objectivist role conception ("Journalists claim the existence of an objective and ultimate truth 'out there' that ought to be 'mirrored' and not be created, invented, or altered in any way" [Hanitzsch 2007, 376]). Both role conceptions represent what we call the "factual" pole, a way of reporting that claims to deliver the given facts rather than the subjective view of the reporter. In contrast, a preference for providing context about, and analysis of, current affairs corresponds to the opposing subjectivist or analytical pole. 
We found that German journalists are significantly more inclined towards the analytical pole than British journalists (see Figure 1).

Our fourth hypothesis is, therefore, confirmed: British journalists tend more towards a role conception that believes in factual reporting, whereas German journalists perceive their role to be more analytical.

The regression analysis also shows that journalists working for online editions of offline outlets are more inclined towards the subjectivist/analytical pole. Journalists working for media outlets with only local or regional reach - as opposed to national reach - tend more towards the factual pole (see Table 2).

\section{Journalists' Conception of their Ethical Role}

Ethical ideology. Drawing on Plaisance (2006), who in turn was inspired by the psychologist Donelson R. Forsyth (1980, 1981), Hanitzsch suggests ethical ideology can be situated along two dimensions: relativism and idealism $(2007,378)$. Relativism describes the extent to which individual moral philosophies are based on universal rules, while idealism denotes the belief that desirable outcomes should always be obtained by morally desirable actions (ibid.). Following Forsyth, these two dimensions can be combined to produce

\footnotetext{
a classification of four ethical ideologies: Situationists are idealistic, but they are also relativistic [...]. Absolutists are also idealistic [...]. Subjectivists, like situationists, base their judgments on personal values and perspectives rather than universal ethical principles. However, unlike situationists they feel that negative behaviour is sometimes necessary to produce good. Finally, exceptionists allow moral absolutes to guide their judgments but remain pragmatically open to exceptions in so far as these help to prevent negative consequences (Hanitzsch 2007, 379).
}

We measured the ethical ideology among our two samples by asking about the extent to which they agreed or disagreed with the following role conceptions: "journalists should always adhere to codes of professional ethics, regardless of situation and context" (absolutist); "what is ethical in journalism depends on the specific situation" (situationist); "what is ethical in journalism is a matter of personal judgement" (subjectivist); and "it is acceptable to set aside moral standards if extraordinary circumstances require it" 
(exceptionist). To create a score for journalists' ethical ideology we located these four role conceptions on a scale where one pole represents an absolutist ethical ideology - that is, an ideology that insists on the existence of universal rules that should always be fulfilled by morally desirably actions - and the opposing pole represents an ideology that allows for subjectivist ethical rules and a subjectivist judgement about whether actions are permitted if they produce a morally desirably outcome. Therefore, the ethical ideology score consists of four role conceptions, with the absolutist role conception at one end of the scale, and the situationist, subjectivist, and exceptionist roles at the other end.

We found that journalists in the UK and Germany differed significantly regarding their ethical ideology. German journalists are significantly more inclined towards an absolutist ethical ideology than their British colleagues (see Figure 1).

This confirms our hypothesis 5a: our data show that British journalists, more than German journalists, tend towards an ethical ideology that places more importance in their own judgement than in conforming with fixed rules.

Ethical practices. We measured attitudes towards various questionable journalistic practices. The ethical practices score was created in two steps. First, we combined several role indicators to describe four ethical role conceptions: payment and pressure (measuring attitudes towards paying people for confidential information, accepting money from sources, and exerting pressure on unwilling informants to get a story), using material without permission (measuring attitudes towards using confidential business or government documents without authorization, and making use of personal documents such as letters and pictures without permission), misrepresentation and subterfuge (measuring attitudes towards claiming to be somebody else, getting employed in a firm or organization to gain inside information, and using hidden microphones or cameras), and verification (measuring attitudes towards publishing stories with unverified content). In a second step, we combined the four role conceptions into a single score to measure differences in attitudes towards conforming to standard ethical practices.

Although there are differences at the level of role indicators, with German journalists less likely to approve using material without permission, but more likely to justify publishing stories with unverified content, we found no difference between British and German journalists at the overall level of adhering to generally accepted ethical practices. 
Therefore, our hypothesis $5 \mathrm{~b}$ is rejected: British journalists are not more prepared than their German colleagues to find justification for questionable ethical practices (see Figure 1).

In contrast to the British sample, the German sample excluded business-to-business ("trade") and highly specialized magazines. We identified journalists within the British sample working for such magazines and conducted a sensitivity analysis which showed that the inclusion of such journalists in the British sample had no relevant effects on our results (see Figure A5 in the online Supplemental Data). Furthermore, sensitivity analyses were conducted on a number of other covariates, including interview mode, type of employment (full-time, part-time, or freelance; permanent or temporary), membership of a professional organization or association for journalists, and salary. The sensitivity analyses showed the latter three covariates had no relevant impact on the country effects (see Figures A1, A2, and A3 in the online Supplemental Data). However, we did find that the interview mode had an effect on the analysis. Removing the 69.2 per cent of German journalists who were interviewed by telephone and only comparing UK and German journalists who completed an online survey shows that, contrary to our overall results, journalists in large German newsrooms who completed an online survey are significantly less inclined to an interventionist role than their British colleagues. Furthermore, German journalists in large newsrooms who completed an online questionnaire were more likely to find justification for questionable ethical practices than their colleagues in the UK (see Figure A4 in the online Supplemental Data).

\section{Discussion}

British and German journalism cultures are closely aligned. Both are strongly influenced by the journalistic ideology of Western elective democracies: neutral and factual reporting, critical distance from power, and adherence to professional ethical rules (Deuze 2005, 445; Hanitzsch 2011). However, our analyses show that they also differ significantly in the extent to which they adhere to this ideology.

Journalists in the UK and Germany diverge in how they relate to "the powers that be" (Hanitzsch 2007, 373), in how they view the reporting of truth, and in their ethical ideology. Three of our six hypotheses were confirmed. British journalists tend to perceive their role as more confrontational to those in power than their German colleagues do. They also lean more towards factual reporting than journalists in Germany, who believe it to be more important to 
provide context and analysis. In their ethical ideology, journalists in the UK stress, as we hypothesized, the importance of personal judgements, whereas German journalists tend more towards conforming to strict rules. However, the difference in ethical ideology is not reflected in journalists' attitudes towards particular practices that might be considered unethical: our hypothesis that British journalists are more prepared than their German colleagues to find justification for questionable ethical practices was not confirmed. Also, contrary to our first hypothesis, journalists in the UK are not more inclined towards an interventionist role than their German colleagues. Furthermore, we didn't find any significant differences in how journalists in the two countries relate to their audiences (our market orientation scale). Thus, our third hypothesis is also rejected. Even so, our results show that British and German journalists diverge within all three constituents of journalism culture.

Our results suggest that journalists in the UK tend more towards the watchdog role, which is characterized by being confrontational and investigative, and which "seeks to hold the government, business and other public institutions accountable, serving as "fourth estate"" (Mellado 2015, 600). Journalists in the UK are also less conformist when it comes to their interpretation of general professional codes of ethics.

Our assumption that journalists in Germany are more invested in their audience as citizens, on the other hand, is only partly supported, in so far as we suggest that the inclination towards an analytical role conception means that German journalists are more interested in providing context to help their audiences live their lives as citizens.

However, there are some other indications that this interpretation may be valid. We analysed journalists' role conceptions through scores measuring different role dimensions. These scores combine a number of single items, each of which represents one specific role conception. A score may, therefore, hide differences between the countries for single items. For example, although our data do not show a significant country difference for the market orientation score, there may be country differences for some single items within that score, for instance "motivating people to participate in political activity" or "providing information people need to make political decisions". Journalists in our German sample show a higher mean for both items than journalists in the British sample (see Table A1 in the online Supplemental Data). We refrained, however, from the analysis of single items due to the inflation of alpha error owing to multiple testing.

The sensitivity analysis for interview mode revealed a significant country difference in the interventionism score that the overall analysis did not show (see Figure A4 in the 
online Supplemental Data). German journalists in large newsrooms who completed an online questionnaire tended less towards an interventionist role conception than British journalists. Whatever the reason for this, it does not contradict our conclusion. On the contrary, such a difference supports our characterisation of British journalists as more willing to confront government and politicians, as our first hypothesis - that German journalists are less keen on an interventionist role conception than their British colleagues - seems to be confirmed for those German journalists who work in a large newsroom and completed an online questionnaire.

Our findings contradict earlier research - especially Köcher (1986), Donsbach and Klett (1993), and Donsbach and Patterson (2004) - which found British journalists to be less active and confrontational than their German colleagues. In particular, our results diverge from Köcher's with regard to questionable journalistic practices. Köcher found that British journalists were far more prepared than their German counterparts to use what she called "dishonest research methods" $(1986,62)$ such as "paying people for confidential information". We found no such general difference. Although the British journalists in our study put more emphasis on individual judgement, they did not find justification for questionable journalistic practices significantly more than journalists in Germany.

Köcher (1986), and other earlier studies are not, however, strictly comparable to ours. They focused on political journalists, whereas we surveyed journalists of all beats. Also, these earlier studies employed different questionnaires and, in the case of Köcher, additional research methods. Even so, the contrast between these earlier findings and our own is striking enough to warrant further investigation. One possible explanation for the change that may have taken place is a remarkable increase in the level of education of journalists. Köcher (1986) stated that, in 1977, just 10 per cent of British journalists had a university degree, whereas a third of German journalists did (50). This compares to 86 per cent of British journalists in our sample who have at least a bachelor's degree (Thurman 2016b, 11), and 64.4 per cent of journalists in the German sample who hold the equivalent to a master's degree, with a further 3.9 per cent having a PhD (Steindl, Lauerer, and Hanitzsch 2017, 414). While Köcher (1986) concluded that the different level of education "suggests that in Great Britain journalism is a career which is less attractive to intellectuals to begin with [...] than in the Federal Republic", this certainly cannot be stated any more. Not only has the level of education risen considerably over the last 40 years, but now more British than German journalists in our samples have a university education. Journalism in the UK has become the 
occupation of a highly educated class, which could explain the possible shift towards a role conception that involves confronting powerful players within society. Education, though, is not the only area of change in the media industry since the 1980s and 1990s. Dramatic changes in the journalistic business model and in production and distribution technologies, as well as the rise of alternative platforms that constitute a public sphere, all may have contributed to a change in journalism cultures.

\section{Conclusion}

Notable recent research on journalism's function in society has utilized multi-country analysis (see, e.g., Hanitzsch 2011; Hanitzsch et al. 2011; de Vreese, Esser, and Hopmann 2017). While such an approach has advantages, we believe that two-country comparisons still have a place in comparative survey research. This study is not only based on data collected within the Worlds of Journalism Study, but also utilizes the theoretical framework of journalism culture constituents that was conceived as "the theoretical backbone of the study" (Hanusch and Hanitzsch 2017, 527). The Worlds of Journalism Study was developed to allow comparisons of journalism cultures across the globe for a substantial number of countries (researchers from 67 countries participated in the second phase) while at the same time overcoming methodological inconsistencies and limitations of previous comparative research (Hanusch and Hanitzsch 2017, 526).

Our study shows that the same framework can be fruitfully applied to the comparison of two close journalism cultures. We found significant differences between the British and German journalism cultures for two constituents and one dimension of a constituent of these cultures. We conclude that British and German journalists differ in their "philosophical" approach - how they "legitimate their role in society and render their work meaningful to themselves and others" (Hanitzsch 2007, 369). Our data show that British journalists conceive their role in a more confrontational fashion, whereas German journalists tend towards a role as facilitators, providing context and analysis for their audience. Although the two media cultures are closely related, journalists in these countries clearly differ in how they perceive their role in society. This difference appears to be echoed in the difference between British and German news content that we noted at the beginning of our article. It is beyond the scope of our investigation to establish how the differing journalism cultures in these 
countries influence media output. However, our results indicate that further research in this area could be fruitful.

Furthermore, our results appear to contradict earlier comparative research into professional attitudes in Britain and Germany. These previous comparisons, however, applied different research designs from our own, which makes the results difficult to compare. Because our study utilizes the common methodological framework of a wider and, importantly, ongoing research project, it may be able to serve as the first in a sequence of investigations into the evolution of two close journalism cultures in a rapidly changing media landscape.

Finally, comparing two countries within the WJS framework rather than a larger number proved to be fruitful for investigating the nature of cross-country research. Even though the data we worked with were gathered according to a common methodological framework, we found differences in interview modes had significant effects. Such differences become more and more difficult to detect, and account for, as the number of countries being compared increases.

Our article's main limitation concerns the "conceptual ambiguity" that it is hard to avoid when surveying journalists' role conceptions (Hanitzsch, Hanusch, and Lauerer 2016, 15). Do journalists' answers reveal what they actually do, what they think they do, or what they aspire to do? Although we acknowledge this ambiguity, we also believe that understanding role conceptions - as well as the nature of journalistic output and the structure of media systems - is necessary in order to fully comprehend journalists' role in society.

\section{NOTES}

1. www.worldsofjournalism.org

2. Weaver's compilations of the "Global Journalist" (Weaver 1998; Weaver and Willnat 2012) are exceptional in this respect as they bring together a number of single-country studies in order to combine them into a comparative overview.

3. For example, recently: Jones (2017) and Harris (2017).

4. For example, not only German newspapers, but even German public broadcast media, which are obliged to report neutrally, breached their obligation to be neutral when reporting the Greek debt crisis (see, e.g., Otto, Köhler, and Baars 2016). 
5. Schönbach, Stürzebecher, and Schneider (1994) vehemently reject Köcher's thesis as well as similar conservative criticism, which, they say, berated German journalists of the leftwing “68er” generation for a patronizing, "schoolmasterly” (“Oberlehrer”) approach to journalism. They base their decisive objection to this reproach on a representative survey of 983 West German journalists and 477 journalists who used to work in East Germany, which they claim to be the first representative survey of German journalists.

6. The regression coefficients describe the effects the respective covariate has on average, and under the condition that all other covariates are held constant. As this is true for all regression coefficients we do not mention it explicitly throughout the rest of this article.

\section{REFERENCES}

Albæk, Erik, Arjen van Dalen, Nael Jebril, and Claes H. de Vreese. 2014. Political Journalism in Comparative Perspective. Cambridge: Cambridge University Press.

Bangel, Christian, Philip Faigle, Andreas Loos, Michael Schultheiß, Milan Bargiel, and Paul Blickle. 2018. "Start Debating! ZEIT ONLINE Matched Up 1,200 People across Germany to Meet Up for Face-to-Face Political Debates. How Did We Do It? Here's a Look behind the Scenes." Zeit Online, 9 March.

https://www.zeit.de/gesellschaft/2018-03/germany-talks-match-debate-politicsenglish/komplettansicht

Cammaerts, Bart, Brooks DeCillia, João Magalhães, and César Jiminez-Martínez. 2017. Journalistic Representations of Jeremy Corbyn in the British Press: From Watchdog to Attackdog. London: Media@LSE Report.

http://www.lse.ac.uk/media@1se/research/pdf/JeremyCorbyn/Cobyn-Report.pdf.

Chorley, Matt. 2018. "Why Paul Dacre's Departure from the Daily Mail Is Bad News for Theresa May on Brexit." The Times, 7 June. https://www.thetimes.co.uk/article/whypaul-dacres-departure-from-the-daily-mail-is-bad-news-for-theresa-may-on-brexit$\underline{\text { lc6tsh } 98 \mathrm{~h}}$

Curran, James, Ivor Gaber, and Julian Petley. 2005. Culture Wars: The Media and the British Left. Edinburgh: Edinburgh University Press. 
Deuze, Mark. 2002. "National News Cultures: A Comparison of Dutch, German, British, Australian, and U.S. Journalists." Journalism and Mass Communication Quarterly 79 (1): 134-149.

Deuze, Mark. 2005. "What is Journalism? Professional Identity and Ideology of Journalists Reconsidered.” Journalism 6 (4): 442-464.

De Vreese, Claes, Frank Esser, and David Nicolas Hopmann, eds. 2017. Comparing Political Journalism. London: Routledge.

Donsbach, Wolfgang. 1983. "Journalists' Conceptions of their Audience: Comparative Indicators for the Way British and German Journalists Define their Relations to the Public." Gazette 32 (1): 19-36.

Donsbach, Wolfgang. 1995. "Lapdogs, Watchdogs and Junkyard Dogs.” Media Studies Journal 9 (4): 17-31.

Donsbach, Wolfgang. 2015. “Journalists' Role Perception.” In The Concise Encyclopedia of Communication, edited by Wolfgang Donsbach, 316-318. Chichester: Wiley Blackwell.

Donsbach, Wolfgang, and Bettina Klett. 1993. "Subjective Objectivity: How Journalists in Four Countries Define a Key Term of their Profession." Gazette 51 (1): 53-83.

Donsbach, Wolfgang, and Thomas E. Patterson. 2004. "Political News Journalists: Partisanship, Professionalism, and Political Roles in Five Countries.” In Comparing Political Communication: Theories, Cases, and Challenges, edited by Frank Esser and Barbara Pfetsch, 251-270. Cambridge: Cambridge University Press.

Esser, Frank. 1998a. Die Kräfte hinter den Schlagzeilen: Englischer und deutscher Journalismus im Vergleich [The forces behind the headlines: Comparing English and German journalism]. Freiburg: Alber.

Esser, Frank. 1998b. "Editorial Structures and Work Principles in British and German Newsrooms." European Journal of Communication 13 (3): 375-405.

Esser, Frank. 1999. ““Tabloidization’ of News: A Comparative Analysis of Anglo-American and German Press Journalism.” European Journal of Communication 14 (3): 291324.

Esser, Frank. 2008. "Dimensions of Political News Cultures: Sound Bite and Image Bite News in France, Germany, Great Britain and the United States." The International Journal of Press/Politics 13 (4): 401-428. 
Esser, Frank, Carsten Reinemann, and David Fan. 2000. "Spin Doctoring in British and German Election Campaigns: How the Press Is Being Confronted with a New Quality of Political PR.” European Journal of Communication 15 (2): 209-239.

Forsyth, Donelson R. 1980. "A Taxonomy of Ethical Ideologies." Journal of Personality and Social Psychology 39 (1): 175-184.

Forsyth, Donelson R. 1981. "Moral Judgment: The Influence of Ethical Ideology." Personality and Social Psychology Bulletin 7 (2): 218-223.

Gaber, Ivor. 2014. 'The 'Othering' of 'Red Ed', or How the Daily Mail 'Framed' the British Labour Leader.” Political Quarterly 85 (4): 471-479.

Godler, Yigal, and Zvi Reich. 2013. "How Journalists Think about Facts.” Journalism Studies 14 (1): 94-112.

Hallin, Daniel C., and Paolo Mancini. 2004. Comparing Media Systems: Three Models of Media and Politics. Cambridge: Cambridge University Press.

Hanitzsch, Thomas. 2007. "Deconstructing Journalism Culture: Toward a Universal Theory." Communication Theory 17 (4): 367-385.

Hanitzsch, Thomas. 2011. "Populist Disseminators, Detached Watchdogs, Critical Change Agents and Opportunist Facilitators: Professional Milieus, the Journalistic Field and Autonomy in 18 Countries.” International Communication Gazette 73 (6): 477-494. Hanitzsch, Thomas, Folker Hanusch, and Corinna Lauerer. 2016. "Setting the Agenda, Influencing Public Opinion, and Advocating for Social Change: Determinants of Journalistic Interventionism in 21 Countries.” Journalism Studies 17 (1): 1-20.

Hanitzsch, Thomas, Folker Hanusch, Claudia Mellado, Maria Anikina, Rosa Berganza, Incilay Cangoz, Mihai Coman, Basyouni Hamada, María Elena Hernández, Christopher D. Karadjov, Sonia Virginia Moreira, Peter G. Mwesige, Patrick Lee Plaisance, Zvi Reich, Josef Seethaler, Elizabeth A. Skewes, Dani Vardiansyah Noor, and Edgar Kee Wang Yuen. 2011. "Mapping Journalism Cultures across Nations.” Journalism Studies 12 (3): 273-293.

Hanusch, Folker, and Thomas Hanitzsch. 2017. "Comparing Journalistic Cultures across Nations." Journalism Studies 18 (5): 525-535.

Hardy, Jonathan. 2008. Western Media Systems. New York: Routledge. Harris, John. 2017. “If Journalists Take Sides, Who Will Speak Truth to Power?” The Guardian, 6 October. 


\section{https://www.theguardian.com/commentisfree/2017/oct/06/journalists-takes-sides-} truth-to-power-activists.

Hellmueller, Lea, and Claudia Mellado. 2015. "Professional Roles and News Construction: A Media Sociology Conceptualization of Journalists' Role Conception and Performance." Communication and Society 28 (3): 1-11.

Hovden, Jan Fredrik. 2014. "To Intervene or Be Neutral, to Investigate or Entertain? National and Intranational Factors in the Formation of Nordic Journalism Students' Role Perceptions." Journalism Practice 8 (5): 646-659.

Jones, Owen. 2017. "We Can No Longer Pretend the British Press Is Impartial." The Guardian, 9 October. https://www.theguardian.com/commentisfree/2017/oct/09/nolonger-pretend-british-press-impartial-country-moreleftwing?utm_source=esp\&utm_medium=Email\&utm_campaign=Media + briefing +20 $16 \& u$ tm term $=247308 \&$ subid $=11880742 \& \mathrm{CMP}=$ ema 546.

Kim, Min-Sun, and John E. Hunter. 1993. "Attitude-Behavior Relations: A Meta-Analysis of Attitudinal Relevance and Topic." Journal of Communication 43 (1): 101-142.

Köcher, Renate. 1986. "Bloodhounds or Missionaries: Role Definitions of German and British Journalists." European Journal of Communication 1 (1): 43-64.

Lindner, Peter, Sebastian Gierke, Sabrina Ebitsch, Jan Heidtmann, and Bernd Kastner. 2017. „Besser mitreden - willkommen im Democracy Lab.“ [Better join in the conversation - welcome to the Democracy Lab.] Süddeutsche Zeitung, 26 June.

http://www.sueddeutsche.de/politik/neues-sz-projekt-besser-mitreden-willkommenim-democracy-lab-1.3545699

Mellado, Claudia. 2015. "Professional Roles in News Content." Journalism Studies 16 (4): 596-614.

Mellado, Claudia, and Arjen van Dalen. 2014. "Between Rhetoric and Practice: Explaining the Gap between Role Conception and Performance in Journalism." Journalism Studies 15 (6): 859-887.

Otto, Kim, Andreas Köhler, and Kristin Baars. 2016. „Die Griechen provozieren! “ Die öffentlich-rechtliche Berichterstattung über die griechische Staatsschuldenkrise ["The Greeks provoke!" How public broadcasters covered the Greek debt crisis]. Frankfurt am Main: Otto Brenner Stiftung.

Pihl-Thingvad, Signe. 2015. "Professional Ideals and Daily Practice in Journalism." Journalism 16 (3): 392-411. 
Plaisance, Patrick Lee. 2006. “An Assessment of Media Ethics Education: Course Content and the Values and Ethical Ideologies of Media Ethics Students.” Journalism and Mass Communication Educator 61 (4): 378-396.

Plaisance, Patrick Lee, Elizabeth A. Skewes, and Thomas Hanitzsch. 2012. "Ethical Orientations of Journalists around the Globe: Implications from a Cross-national Survey." Communication Research 39 (5): 641-661.

Sanders, Karen, and Mark Hanna. 2012. "British Journalists.” In The Global Journalist in the $21^{\text {st }}$ Century, edited by David H. Weaver and Lars Willnat, 220-233. New York: Taylor \& Francis.

Schönbach, Klaus, Dieter Stürzebecher, and Beate Schneider. 1994. „Oberlehrer oder Missionare? Das Selbstverständnis deutscher Journalisten. “ [Schoolmasters or missionaries? German journalists` self-conception.] Kölner Zeitschrift für Soziologie und Sozialpsychologie, edited by Friedhelm Neidhardt. Sonderheft 34: 139-161.

Schudson, Michael, and Chris Anderson. 2008. "Objectivity, Professionalism, and Truth Seeking in Journalism.” In: The Handbook of Journalism Studies, edited by Karin Wahl-Jorgensen and Thomas Hanitzsch, 88-101. London: Routledge.

Semetko, Holli A., Jay G. Blumler, Michael Gurevitch, David H. Weaver, Steve Barkin, and G. Cleveland Wilhoit. 1991. The Formation of Campaign Agendas: A Comparative Analysis of Party and Media Roles in Recent American and British Elections. Hillside, NJ: Lawrence Erlbaum Associates.

Steindl, Nina, Corinna Lauerer, and Thomas Hanitzsch. 2017. „Journalismus in Deutschland: Aktuelle Befunde zu Kontinuität und Wandel im deutschen Journalismus." [Journalism in Germany: Current results on continuity and change within German journalism.] Publizistik 62 (4): 401-423.

Tandoc, Edson C., Lea Hellmueller, and Tim P. Vos. 2013. "Mind the Gap: Between Journalistic Role Conception and Role Enactment.” Journalism Practice 7 (5): 539_ 554.

Thurman, Neil. 2016a. "Methodology." In Journalists in the UK, edited by Neil Thurman, Alessio Cornia, and Jessica Kunert, 56-59. Oxford: Reuters Institute fort he Study of Journalism.

Thurman, Neil. 2016b. "Personal Characteristics and Diversity." In Journalists in the UK, edited by Neil Thurman, Alessio Cornia, and Jessica Kunert, 8-14. Oxford: Reuters Institute fort he Study of Journalism. 
Tschermak, Moritz. 2017. „Endlich! Die Bild als Wahlkampfblatt für die AfD!““ [Finally! Bild as election campaign paper for the AfD!] Bildblog, 18 July. http://www.bildblog.de/91306/endlich-die-bild-als-wahlkampfblatt-fuer-die-afd/ Umbricht, Andrea, and Frank Esser. 2014. "Changing Political News? Long-term Trends in American, British, French, Italian, German, and Swiss Print Media Reporting.” In Political Journalism in Transition: Western Europe in a Comparative Perspective, edited by Raymond Kuhn and Rasmus Kleis Nielsen, 195-217. London: I.B. Tauris.

Van Dalen, Arjen, Claes H. de Vreese, and Erik Albæk. 2012. "Different Roles, Different Content? A Four-country Comparison of the Role Conceptions and Reporting Style of Political Journalists.” Journalism 13 (7): 903-922.

Waterson, Jim. 2018. "New Daily Mail Editor to Be Geordie Greig: Pro-remain Editor of Mail on Sunday to Replace Paul Dacre at Top of Brexit-supporting Paper." The Guardian, 7 June. https://www.theguardian.com/media/2018/jun/07/new-daily-maileditor-to-be-geordie-greig

Weaver, David H., ed. 1998. The Global Journalist: News People around the World. Creskill, NJ: Hampton Press.

Weaver, David H., and Lars Willnat, eds. 2012. The Global Journalist in the $21^{\text {st }}$ Century. New York: Taylor \& Francis.

WJS. 2012a. Field Manual: Instructions for Field Research. http://www.worldsofjournalism.org/fileadmin/Data_tables_documentation/Document ation/Field Manual 1.3.pdf

WJS. 2012b. Master Questionnaire. Version 2.5.1. consolidated. http://www.worldsofjournalism.org/fileadmin/Data_tables_documentation/Document ation/WJS_core_questionnaire_2.5.1_consolidated.pdf

Zelizer, Barbie. 2005. "The Culture of Journalism." In Mass Media and Society, $4^{\text {th }}$ edition, edited by James Curran and Michael Gurevitch, 198-214. London: Hodder Arnold. 

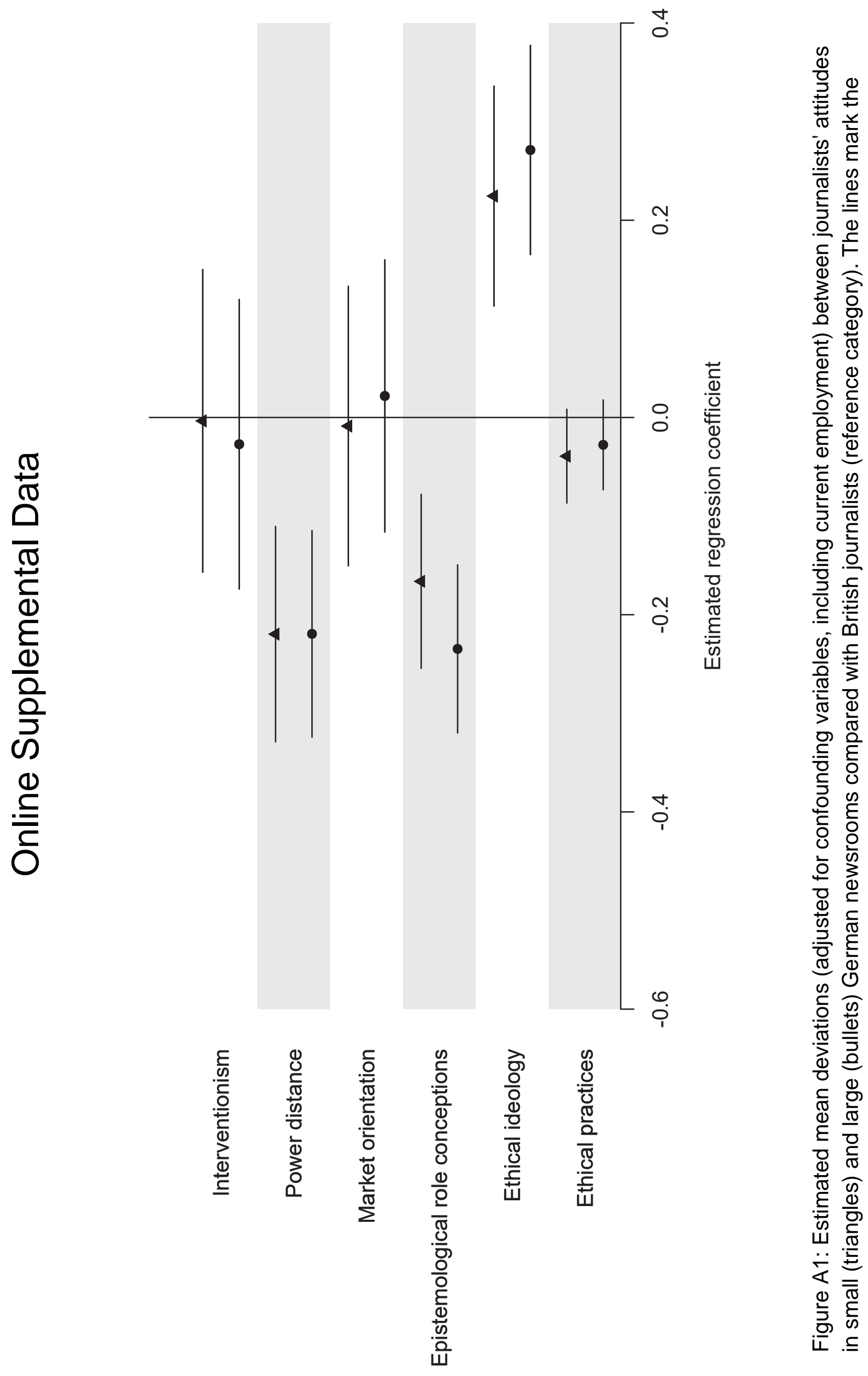

है

응 बํㅣ

ह $\frac{0}{\Phi}$

둥

文

을 흠

흥 도

.

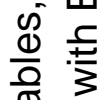

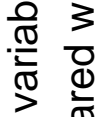

을 을

은

응 응

으 ‘

일

옹

를 ह

త্

क क त

莽 志 $\stackrel{\frac{0}{.}}{=}$

잉

잉

ฮ 즈

흥 음

ثี

ह

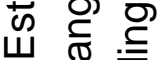

들

依

๑ ฮ

亭 


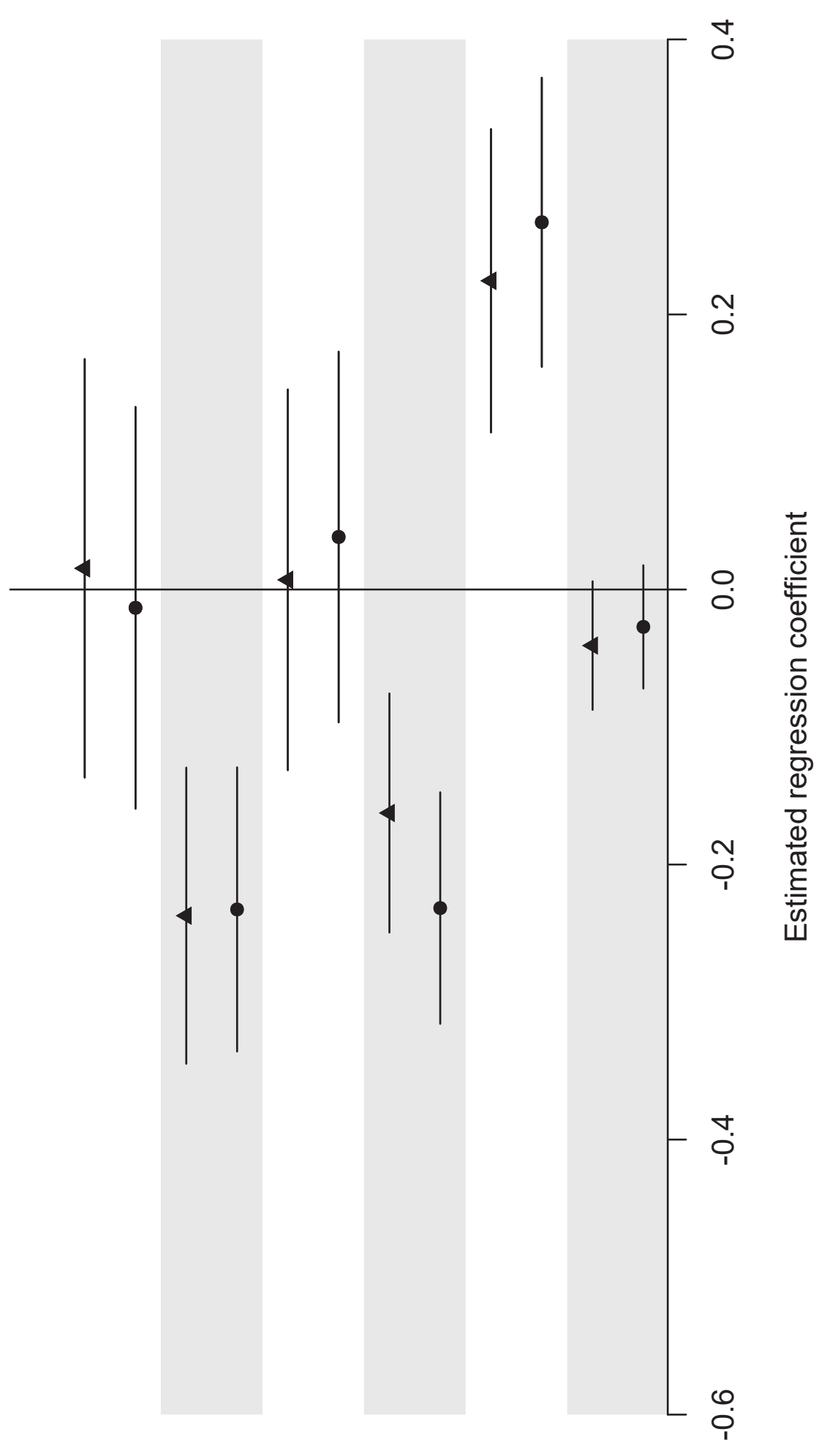

N

O

过

के

음

N

즘

잉 ్ㅗㅇ

즈음

응 $\frac{\text { 옹 }}{=}$

ब

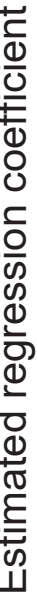

흔 둔

¿

을 일

के है

ॠ

당

흥

긍

क)

$>$

읗

ᄃ

은 옹

ठ․

훈 $\frac{0}{\sigma}$

$\overline{0} \frac{}{0}$

क 0

司

웅

등 品

क क

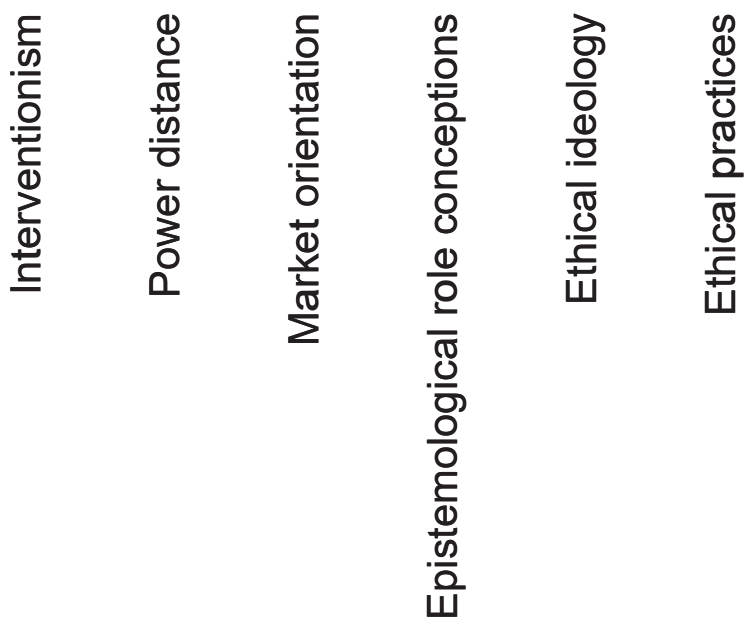

증

응

등 응

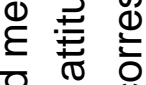

잉

苋

施

山

安 응

๑

言送这 

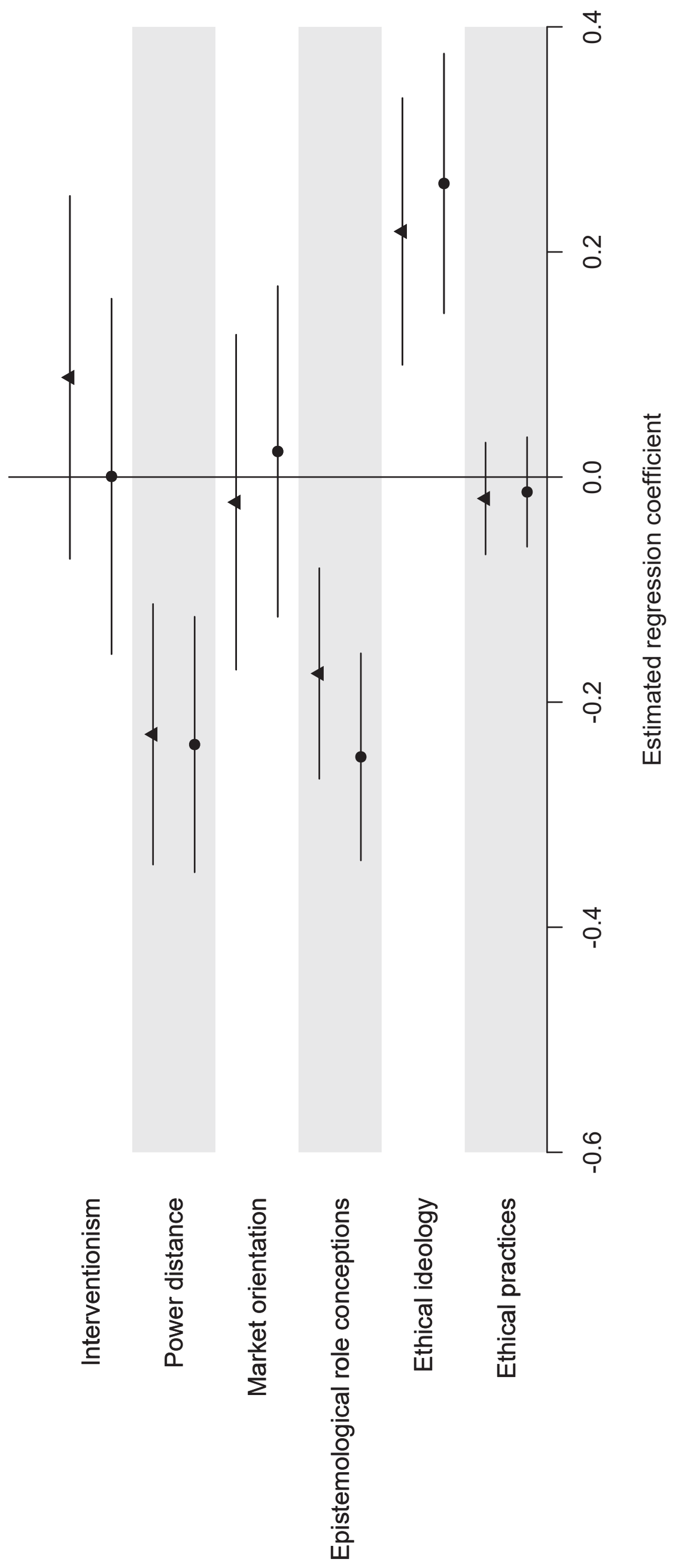

ह

$\stackrel{9}{\oplus}$

음 논

$\stackrel{\text { Е }}{E}$

क

을

㤐

읃 홍

ธิ 잉

$\sum_{0}^{ \pm}$

을

离

क ष

을

흘

을

क. 으

즌

गั

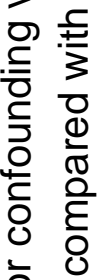

히

일

高 क

త్ర Ð

थ ट त

등 통

刃

क

듀웡

๕

잉 ㅇํㅇ

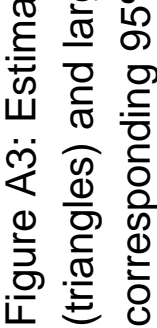




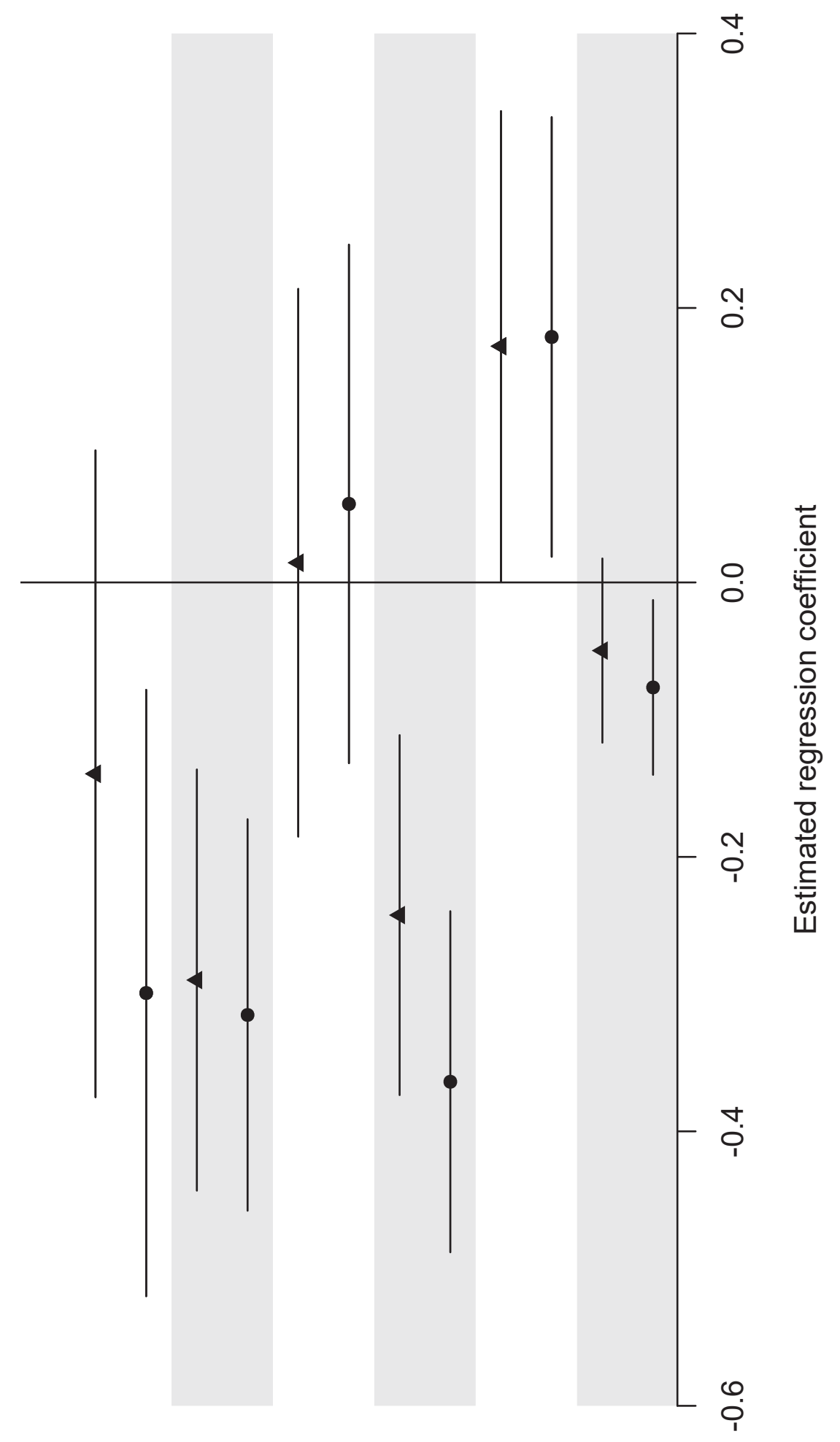

क्ष

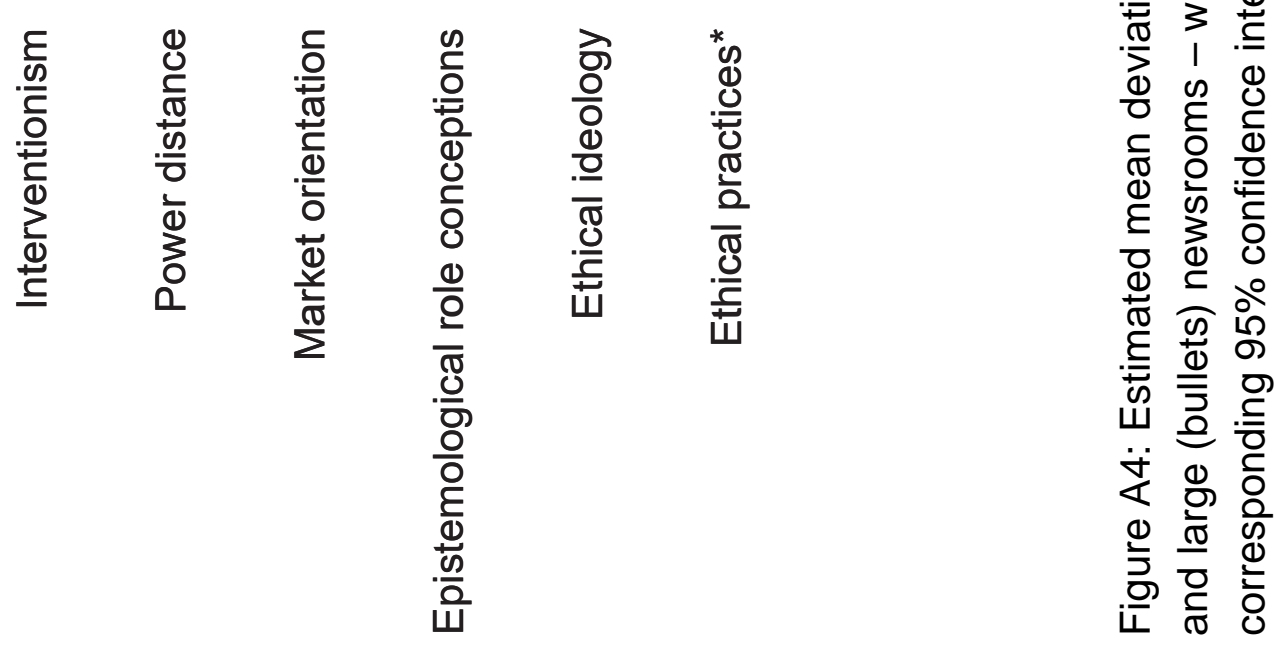



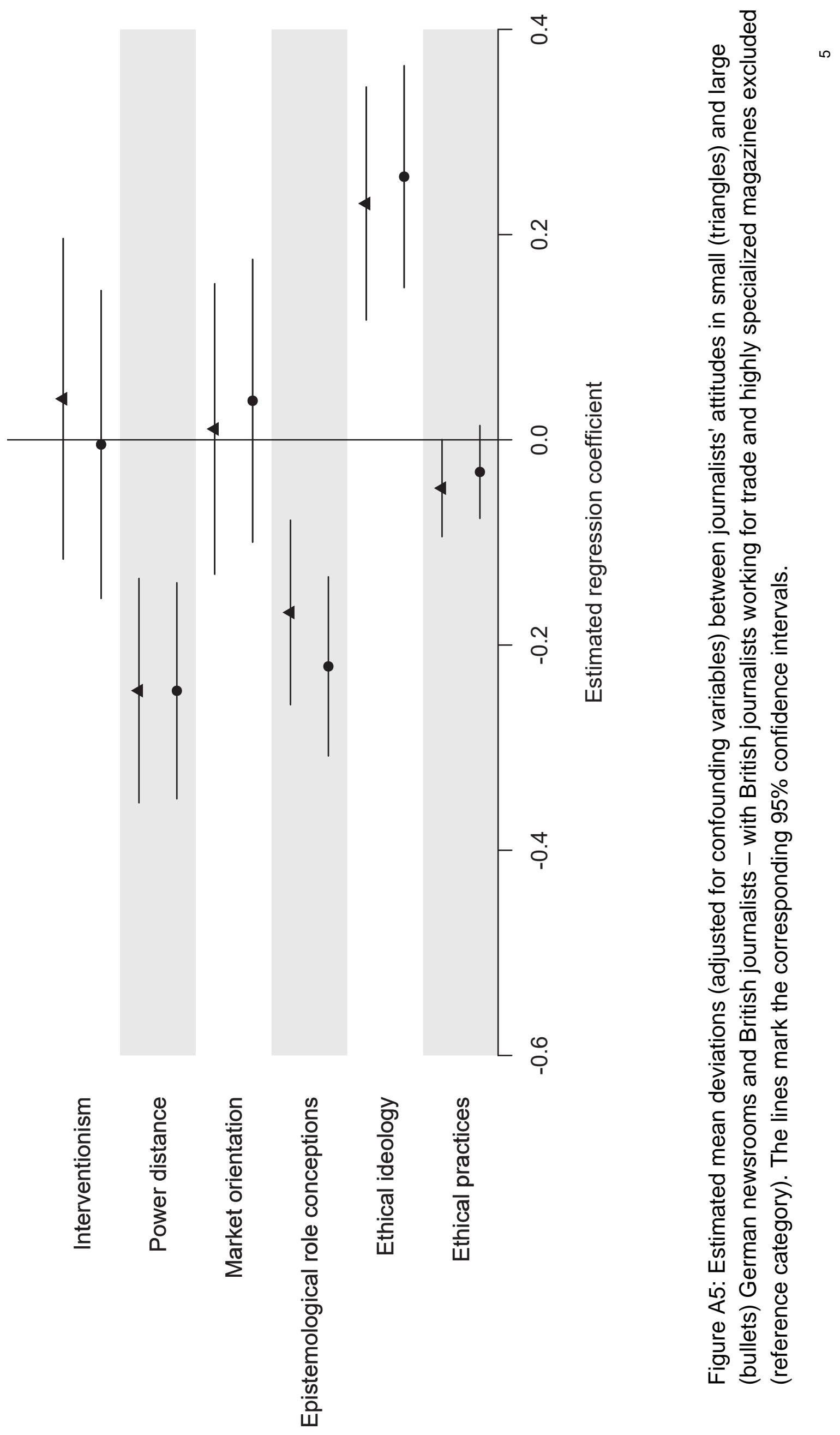

을

음 ช্ত

으 흔

당

$\sum_{1}^{0} \frac{\bar{x}}{\bar{x}}$

๑)

क $\frac{\infty}{\omega}$.

엉

훈으 음

돋 등

อ ตे

은 ㅇํㅇ

응 인

흔

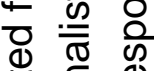

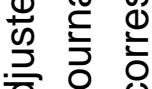

త્ฮ

을

을 을

ฮ

ธิ

ह 을

잉

芯

Ш

i்

(1)

章言高 


\begin{tabular}{|c|c|c|c|c|}
\hline & All & $\begin{array}{c}\text { Small German } \\
\text { newsrooms }\end{array}$ & $\begin{array}{l}\text { Large German } \\
\text { newsrooms }\end{array}$ & UK \\
\hline INTERVENTIONISM & $2.809(0.875)$ & $2.882(0.787)$ & $2.825(0.857)$ & $2.758(0.928)$ \\
\hline Set the political agenda & $2.187(1.115)$ & $2.132(1.069)$ & $2.056(1.041)$ & $2.288(1.169)$ \\
\hline Influence public opinion & $2.701(1.14)$ & $2.721(1.118)$ & $2.646(1.132)$ & 2.719 (1.157) \\
\hline Advocate for social change & $2.769(1.25)$ & $2.779(1.19)$ & $2.764(1.239)$ & $2.766(1.289)$ \\
\hline Promote tolerance and cultural diversity & $3.526(1.333)$ & $3.836(1.153)$ & $3.755(1.268)$ & $3.22(1.398)$ \\
\hline POWER DISTANCE & $3.531(0.672)$ & $3.509(0.714)$ & $3.429(0.709)$ & $3.599(0.618)$ \\
\hline Monitor and scrutinize political leaders & $3.015(1.484)$ & $2.889(1.46)$ & $2.692(1.448)$ & $3.261(1.477)$ \\
\hline Monitor and scrutinize business & $3.19(1.409)$ & $2.832(1.372)$ & $2.776(1.415)$ & $3.612(1.303)$ \\
\hline Be an adversary of the government & $2.11(1.215)$ & $2.355(1.321)$ & $2.184(1.27)$ & $1.929(1.087)$ \\
\hline Support government policy (reversed) & $4.683(0.622)$ & $4.723(0.581)$ & $4.735(0.579)$ & $4.631(0.664)$ \\
\hline Support government policy & $1.317(0.622)$ & $1.277(0.581)$ & $1.265(0.579)$ & $1.369(0.664)$ \\
\hline $\begin{array}{l}\text { Convey a positive image of political leadership } \\
\text { (reversed) }\end{array}$ & $4.666(0.661)$ & $4.747(0.58)$ & $4.76(0.558)$ & $4.568(0.74)$ \\
\hline Convey a positive image of political leadership & $1.334(0.661)$ & $1.253(0.58)$ & $1.24(0.558)$ & $1.432(0.74)$ \\
\hline MARKET ORIENTATION & $3.334(0.851)$ & $3.175(0.871)$ & $3.361(0.9)$ & $3.411(0.8)$ \\
\hline Provide entertainment and relaxation & $3.44(1.189)$ & $3.359(1.108)$ & $3.668(1.054)$ & $3.364(1.285)$ \\
\hline $\begin{array}{l}\text { Provide the kind of news that attracts the largest } \\
\text { audience }\end{array}$ & $3.67(1.111)$ & $4.005(0.965)$ & $4.003(0.938)$ & $3.3(1.157)$ \\
\hline $\begin{array}{l}\text { Provide information people need to make political } \\
\text { decisions (reversed) }\end{array}$ & $2.889(1.47)$ & $2.515(1.395)$ & $2.776(1.491)$ & $3.169(1.446)$ \\
\hline $\begin{array}{l}\text { Provide information people need to make political } \\
\text { decisions }\end{array}$ & $3.111(1.47)$ & $3.485(1.395)$ & $3.224(1.491)$ & $2.831(1.446)$ \\
\hline $\begin{array}{l}\text { Motivate people to participate in political activity } \\
\text { (reversed) }\end{array}$ & $3.317(1.418)$ & $2.8(1.379)$ & $3.003(1.448)$ & $3.799(1.26)$ \\
\hline Motivate people to participate in political activity & $2.683(1.418)$ & $3.2(1.379)$ & $2.997(1.448)$ & $2.201(1.26)$ \\
\hline EPISTEMOLOGICAL ROLE CONCEPTIONS & $3.576(0.492)$ & $3.55(0.47)$ & $3.484(0.486)$ & $3.64(0.498)$ \\
\hline Be a detached observer & $4.195(0.929)$ & $4.332(0.884)$ & $4.206(1.02)$ & $4.111(0.893)$ \\
\hline Report things as they are & $4.592(0.687)$ & $4.621(0.71)$ & $4.558(0.757)$ & $4.593(0.632)$ \\
\hline Provide analysis of current affairs (reversed) & $1.93(1.078)$ & $1.704(0.98)$ & $1.684(0.943)$ & $2.193(1.138)$ \\
\hline Provide analysis of current affairs & $4.07(1.078)$ & $4.296(0.98)$ & $4.316(0.943)$ & 3.807 (1.138) \\
\hline ETHICAL IDEOLOGY & $3.946(0.675)$ & $4.098(0.581)$ & $4.092(0.607)$ & $3.781(0.721)$ \\
\hline Absolutism & $4.582(0.681)$ & $4.609(0.609)$ & $4.588(0.666)$ & $4.563(0.727)$ \\
\hline Situationism (reversed) & $2.69(1.315)$ & $2.867(1.327)$ & $2.834(1.313)$ & $2.512(1.287)$ \\
\hline Subjectivism (reversed) & $3.608(1.204)$ & $3.923(1.048)$ & $3.926(1.052)$ & $3.259(1.265)$ \\
\hline Exceptionism (reversed) & $3.612(1.226)$ & $3.946(1.06)$ & $4.005(1.015)$ & $3.212(1.292)$ \\
\hline ETHICAL PRACTICES & $2.511(0.277)$ & $2.509(0.265)$ & $2.516(0.28)$ & $2.51(0.282)$ \\
\hline Paying people for confidential information & $2.415(0.567)$ & $2.415(0.593)$ & $2.338(0.601)$ & $2.456(0.528)$ \\
\hline Accepting money from sources & $2.957(0.217)$ & $2.951(0.215)$ & $2.962(0.218)$ & $2.957(0.217)$ \\
\hline $\begin{array}{l}\text { Exerting pressure on unwilling informants to get a } \\
\text { story }\end{array}$ & $2.729(0.456)$ & $2.791(0.432)$ & $2.817(0.394)$ & $2.645(0.485)$ \\
\hline $\begin{array}{l}\text { Using confidential business or government } \\
\text { documents without authorization }\end{array}$ & $2.053(0.598)$ & $1.979(0.672)$ & $2.029(0.664)$ & $2.107(0.507)$ \\
\hline $\begin{array}{l}\text { Making use of personal documents such as letters } \\
\text { and pictures without permission }\end{array}$ & $2.682(0.481)$ & $2.83(0.389)$ & $2.824(0.395)$ & $2.519(0.518)$ \\
\hline Claiming to be somebody else & $2.483(0.563)$ & $2.432(0.603)$ & $2.445(0.617)$ & $2.534(0.502)$ \\
\hline $\begin{array}{l}\text { Getting employed in a firm or organization to gain } \\
\text { inside information }\end{array}$ & $2.169(0.563)$ & $2.099(0.63)$ & $2.16(0.602)$ & $2.213(0.493)$ \\
\hline Using hidden microphones or cameras & $2.295(0.546)$ & $2.351(0.632)$ & $2.431(0.564)$ & $2.19(0.456)$ \\
\hline Publishing stories with unverified content & $2.657(0.527)$ & $2.607(0.557)$ & $2.567(0.569)$ & $2.735(0.471)$ \\
\hline
\end{tabular}

Table A1: Means (standard deviations) of items and scores measuring journalists' attitudes in the UK and in small and large German newsrooms. 5-point Likert items were used, with response levels ranging from 1 for "unimportant" to 5 for "extremely important". For all items under "ethical practices" 3-point Likert-type items were used with the following response levels: 1 for "always justified", 2 for "justified on occasion", and 3 for "not approve under any circumstances". 